\title{
David Freestone
}

\section{Publications}

Books/Monographs/Major reports:

1. Conserving Biodiversity in Areas beyond National Jurisdiction (ed.), Brill Nijhoff, 2019, $\mathrm{x}+329 \mathrm{pp}$.

2. International Law and Sea Level Rise. Brill Research Perspectives in the Law of the Sea (Davor Vidas and Donald R Rothwell, eds.), Brill Nijhoff, 2019, ix +87 pp (with Davor Vidas and Jane McAdam).

3. Second Report of the ILA Committee on Sea Level Rise and International Law, Seventy-eighth ILA Conference, Sydney, 2018, 4opp. (with Davor Vidas and Jane McAdam).

4. Sustainable Development and International Environmental Law (ed.) (International Library of Law and the Environment), Edward Elgar, 2018, xxvii + 913pp.

5. World Heritage in the High Seas: An Idea Whose Time has come. Applying Outstanding Universal Value beyond National Jurisdiction. Unesco World Heritage Reports No. 44, July 2016, 69 pp + 21 pp appendices (with Dan Laffoley, Fanny Douvere and Tim Badman).

6. First Interim Report of the ILA Committee on Sea Level Rise and International Law, Seventy-Seventh ILA Conference, Johannesburg, 2016, 28pp (with Davor Vidas and Jane McAdam).

7. $\quad$ The 1982 Law of the Sea Convention at 30: Successes, Challenges and New Agendas (ed.) Martinus Nijhoff, 2013, xviii + 211pp.

8. The World Bank and Sustainable Development - Legal Essays, Martinus Nijhoff, 2012, xiv + 373pp.

9. Climate Change and the Law of the Sea (Guest Editor) Special Issue of Carbon and Climate Law Review Volume 3, 2009, pp. 385-483.

10. Legal Aspects of Carbon Trading: Kyoto, Copenhagen and Beyond (ed., with Charlotte Streck) Oxford University Press, 2009, lviii +657pp.

11. The Kyoto Protocol: Current Legal Status of Carbon Finance and the Flexible Mechanisms, (Guest ed., with Charlotte Streck) Special Issue of Environmental Liability Vol 15, March-April 2007, 47-124.

12. The Law of the Sea: Progress and Prospects (ed., with Richard Barnes and David Ong) Oxford University Press, July 20o6, xxxviii + 457pp.

13. Legal Aspects of Implementing the Kyoto Protocol: making Kyoto work (ed., with Charlotte Streck) Oxford University Press, February 2005, xi + 643pp. 
14. Unfinished Business: Deep-Sea Fisheries and the Conservation of Marine Biodiversity beyond National Jurisdiction (ed. with Kristina Gjerde: IJMCL Special Issue), 2004, Martinus Nijhoff, xi + 156pp.

15. Légiférer pour une gestion durable des pêcheries: Guide de l'Accord de Conformitéde la FAO de 1993 et de l'Accord de l'onU de 1995 sur les Stocks Chevauchants. (avec William Edeson and Elly Gudmundsdottir), World Bank, Washington D.C., 2004, 161 pp (Collection Droit, Justice et Développement).

16. Contemporary Issues in International Law: A Collection of the Josephine Onoh Memorial Lectures (ed. with Surya Subedi and Scott Davidson) Kluwer Law International, The Hague, 2002, xvi + 236 pp.

17. “ “Come Hell or High Water ...” International Law and Sustainable Development in the Twenty-First Century.' (The 2001 Josephine Onoh Memorial Lecture, 1 May 2001) University of Hull Law School, 2001, 37 pp. (Studies in Law Series).

18. Legislating for Sustainable Fisheries: A Guide to Implementing the 1993 FAO Compliance Agreement and the 1995 Fish Stocks Agreement (with William Edeson and Elly Gudmundsdottir), World Bank, Washington D.C., 2001, $15^{2}$ pp. (Law, Justice and Development Series). Translated into French 2004 (above).

19. International Law and Sustainable Development: Past Achievements and Future Challenges (ed. with Alan Boyle) 1999, Oxford University Press, xxx + 365 pp.

20. The Burden of Proof in Natural Resources Legislation: some critical issues for fisheries law. Food and Agriculture Organization of the UN, Rome, 1998, 25 pp. (FAO Legislative Study, No. 63).

21. The Precautionary Principle and International Law: The Challenge of Implementation (ed. with Ellen Hey), 1996, Kluwer Law International, xvii $+274 \mathrm{pp}$.

22. The Law of the Sea Convention: Unfinished Agendas and Future Challenges (ed. with Gerard Mangone: IJMCL Special Issue), 1995, Kluwer Law International, xii and 204pp.

23. Particularly Sensitive Sea Areas: an Important Environmental Concept at a Turning Point (ed., with Kristina Gjerde: IJMCL Special Issue), 1994, Martinus Nijhoff/ Graham and Trotman, xii and 156pp.

24. The Road from Rio: International Environmental Law after the Earth Summit. (Inaugural Lecture at the University of Hull, 14 October 1992) 1993, University of Hull Press, 34pp.

25. International Law and Global Climate Change (ed., with R.R. Churchill), 1991, Graham and Trotman/ Martinus Nijhoff, xviii + 447pp.

26. The North Sea: Basic Legal Documents on Regional Environmental Co-operation, (ed., with T. IJlstra) Graham and Trotman/Martinus Nijhoff, London/Dordrecht, 1991, xx +45 opp. [Volume 1 of Basic Documents on Regional Environmental Co- operation]. 
27. Children and the Law: Essays in Honour of Professor H.K. Bevan (ed.) University of Hull Press, 199o, xxv + 32opp.

28. The North Sea: Perspectives on Regional Environmental Co-operation, (ed., with T. IJlstra) Graham and Trotman/Martinus Nijhoff, London/Dordrecht, 199o, xv + 380 pp.

29. The Institutional Framework of the European Communities (with J. Scott Davidson) 1988, Croom Helm, London and New York, 1988, xvii + 22opp. Second impression, 1991, Routledge.

30. The Humber Estuary (with NV Jones, J North, Js Pethick, D Symes, RC Ward), Executive Summary, 1988, Shell International, 6o pp; Full Report, 1988, Institute of Estuarine and Coastal Studies, $172 \mathrm{pp}$.

\section{Journal Articles and Chapters in Books}

Forthcoming:

31. "Sargasso Sea" Chapter $7 \mathrm{~S}$ in The Second Integrated World Ocean Assessment (First World Ocean Assessment), 2021, United Nations, New York, 7pp (with Howard Roe, Brian Luckhurst Laurie Kell, and Tammy Trott).

32. "Governance of Areas beyond National Jurisdiction: An Unfinished Agenda?" Chapter 13 in (Marta Riberio and Wagner Menezes, eds) Direito do Mar: Regulamentação Normativa dos Espaços Marǐtimos, Arraaes Editores, Belo Horizonte, 2019, pp 289-324.

33. "Strengthening Stewardship of the Sargasso Sea" paper in Proceeding of 2018 Law of the Sea Instutute Meeting New York, (with David Balton) 22pp.

34. "Climate Change, the Anthropocene and Ocean Law: Mapping the Issues" in Richard Barnes, Jan McDonald and Jeff McGee, (eds.) Research Handbook on Climate Change, Oceans and Coasts (Edward Elgar, 2020) 2opp. (with Millicent McCreath).

35. "International Law and the end of the Holocene" for submission to Ocean Development and International Law (with Davor Vidas, Jan Zalasiewicz and Mark Williams).

Published:

36. "Sustainable Development, Ocean Governance and Marine Protected Areas" (2019) 4 Asia-Pacific Journal of Ocean Law and Policy 127-141.

37. "Islands Awash Amidst Rising Seas: Sea Level Rise and Insular Status under the Law of the Sea" in Proceedings of the 2018 Singapore Conference on Climate Change (2019) 34 International Journal of Marine and Coastal Law 391-414 (with Clive Schofield). 
38. "Securing Ocean Spaces for the Future? The Initiative of the Pacific sids to Develop Regional Practice Concerning Baselines and Maritime Zone Limits" (2019) 33 Ocean Yearbook 58-89 (with Clive Schofield).

39. "The UN Process to Develop an International Legally Binding Instrument under the 1982 Law of the Sea Convention: Issues and Challenges" in (David Freestone, Ed.) Conserving Biodiversity in Areas beyond National Jurisdiction, Brill Nijhoff, 2019, pp 3-48.

40. "International Law and Sea Level Rise" (2018) 2 Brill Research Perspectives in the Law of the Sea 1-87 (with Davor Vidas and Jane McAdam).

41. "Remarks" in Panel on "The Regime of Islands in the Aftermath of the South China Sea Arbitration" (2019) Proceedings of the American Society of International Law $1-12$.

42. "An Unfinished Agenda: Governance of Areas beyond National Jurisdiction" in Global Commons and the Law of the Sea, (Keyuan Zou, Ed.), Brill Nijhoff, 2018, 209-225.

43. "The Role of the International Climate Change Regime in Global Ocean Governance" chapter 7 in The IMLI Treatise on Global Ocean Governance Volume I: UN and Global Ocean Governance, (David Attard, David Ong and Dino Kritsiotis, eds.), OUP, 2018, 149-164.

44. "The Limits of Sectoral and Regional Efforts to Designate High Seas Marine Protected Areas" (2018) Asil Unbound Series (Cymie Payne, Ed.) pp. 1-5.

45. "Marine Biodiversity in Areas beyond National Jurisdiction" in The Future of Ocean Governance and Training: Essays in Honour of Elisabeth Mann Borgese (1918-2002), International Ocean Institute, (Canada, eds.), Brill Nijhoff, 2018, pp. 151-155.

46. "Sustainable Development and International Environmental Law" Editor's Introduction. Sustainable Development and International Environmental Law (International Library of Law and the Environment), Edward Elgar, 2018, pp. xvii-xxvi.

47. "Protecting Marine Biodiversity in Areas beyond National Jurisdiction: Instistutional Considerations for a New International Agreement under the United Nations Convention on the Law of the Sea" in The Law of the Sea and Emerging Issues (Guifang (Julia) Xue nd Jie Zheng, eds.) China Democracy and Legal System Publishing House, 2018, pp 39-54 (with Andrew Friedman, Nichola Clark, Joan Yang, Kristina Gjerde and Winnie Lau).

48. "Sustainable Management of Ocean Ecosystems: Some Comments" in Sustainable Ocean Resource Governance: Deep Sea Mining, Marine Energy and Submarine Cables (Markus Kotzur, Nele Matz-Lück, Alexander Proelss, Roda Verheyen and Joachim Sanden, Eds.) Brill Nijhoff, 2018, pp. 134-153. 
49. "Editors' Introduction" Special Issue on Marine Environmental Protection in Asia: Regional Implementation of IMO Conventions (2017) 3 Asia Paciifc Journal of Ocean Law and Policy 195-200 (with Moon Sang Kwon and Seokwoo Lee).

5o. "A World of Difference - Opportunities for applying the World Heritage Convention to the High Seas" (2017) 27 Aquatic Conservation: Marine and Freshwater Ecosystems 1-11 (with Dan Laffoley).

51. "The United Nations Convention on the Law of the Sea (LOSC) and Sustainable Development Jurisprudence" in Sustainable Development Principles in the Decisions of International Courts and Tribunals. (Marie-Claire Cordonier Segger and CG Weeramantry, eds.) London: Routledge 2017, pp. 319-338 (with FreedomKai Phillips).

52. "Sea Level Rise and Impacts on Maritime Zones and Limits: The work of the ILA Committee on Sea Level Rise and International Law" (2017) 3 Korean Journal of International and Comparative Law, pp. 5-35 (with Davor Vidas and Alejandra Torres Camprubí).

53. "Particularly Sensitive Sea Areas beyond National Jurisdiction: Time to Chart a New Course?" in International Marine Economy: Law and Policy (Myron Nordquist, John Norton Moore and Ronan Long, eds.), Brill Nijhoff, 2017, pp. 322361 (with Viva Harris).

54. "Republic of the Marshall Islands: 2016 Maritime Zones Declaration Act: drawing lines in the sea" Current Legal Developments (2016) 31 International Journal of Marine and Coastal Law 720-746 (with Clive Schofield).

55. "The United Nations Framework Convention on Climate Change - the basis for the climate change regime" in Oxford Handbook on International Climate Change Law (Cinnamon Carlarne, Kevin Gray and Richard Tarasoksky, eds.) Oxford University Press, 2016, pp. 101-123.

56. "Case 21: Request for an Advisory Opinion submitted by the Sub-Regional Fisheries Commission (SRFC), International Tribunal for the Law of the Sea" Current Legal Developments (2016) 1 Asia-Pacific Journal of Ocean Law and Policy 126-133.

57. "The Sargasso Sea Commission: An innovative approach to the conservation of areas beyond national jurisdiction" (2016) 30 Ocean Yearbook 80-90 (with Faith Bulger).

58. "Governance of Areas beyond National Jurisdiction: An Unfinished Agenda?" in Law of the Sea: UNCLOS as a Living Treaty, (Jill Barrett and Richard Barnes, eds.) London: British Institute of International and Comparative Law, 2016, pp. 231-266.

59. "Sargasso Sea" Chapter 50 in The First Integrated World Ocean Assessment (First World Ocean Assessment), 2016, United Nations, New York, 7pp (with Howard 
Roe, Lorna Inniss, Dan Laffoley, Jake Rice and Tammy Trott). http://www.un.org/ depts/los/global_reporting/WOA_RPROC/Chapter_5o.pdf

6o. "Submarine Telecommunication Cables in the Sargasso Sea" (2015) 30 International Journal of Marine and Coastal Law 371-378 (with Alice Leonard de Juvigny, Tara M. Davenport and Douglas R. Burnett).

61. "International Law and Sea Level Rise: The New ILA Committee" (2015) 21 (2) International Law Students' Association (ILSA) Journal of International and Comparative Law 397-408 (with Davor Vidas and Jane McAdam).

62. "The Caribbean Sea and Gulf of Mexico" in Oxford Handbook on the Law of the Sea Oxford University Press, 2015, (Don Rothwell, et al, eds.), pp 672-700 (with Clive Schofield).

63. 'Challenging the 'Right to Fish' in a Fast-Changing Ocean" (2014) 33 Stanford Environmental Law Journal/Stanford Journal Of Law, Science, \& Policy pp. 289324 (with Cassandra M. Brooks, John B. Weller, Kristina Gjerde, Rashid Sumaila, Jeff Ardron, Natalie C. Ban, Katherine Seto, Sebastian Unger, Daniel P. Costa, Kara Fisher, Larry Crowder, Patrick Halpin, Andre Boustany, Martin Hall).

64. "The Sargasso Sea Alliance: Working to Protect the 'Golden Floating Rain Forest of the Ocean' " (2014) 44 Environmental Policy and Law 151-158.

65. "Regional Governance for Fisheries and Biodiversity" in Governance for Fisheries and Marine Conservation: interactions and co-evolution. (S.M. Garcia, J. Rice, and A.T. Charles, eds.) Wiley-Blackwell, 2014, pp. 211-224, (with Robin Warner and Kristina Gjerde).

66. "The Signing of the Hamilton Declaration on Collaboration for the Conservation of the Sargasso Sea: A new paradigm for high seas conservation?" (2014) 29 International Journal of Marine and Coastal Law 345-362 (with Kate Killerlain Morrison).

67. "Can existing institutions protect biodiversity in areas beyond national jurisdiction? Experiences from two on-going processes" (2014) 42 Marine Policy 167-175 (with David Johnson, Jeff Ardron, Sebastian Unger, and Kate Killerlain Morrison).

68. "Place-based Dynamic Management of Large Scale Ocean Places: Papahānaumokuākea and the Sargasso Sea" (2014) 33 (2) Stanford Environmental Law Journal 191-248 (with Ole Varmer, Meredith Bennett, 'Aulani Wilhelm, Theodore M. Beuttler, Jeff Ardron, Sara Maxwell and Kate Killerlain Morrison).

69. "Can We Protect High Seas Ecosystems under Current International Law? Lessons from the Sargasso Sea Project" in Proceedings of the International Conference 30 Years after Signature of the United Nations Convention on the Law of the Sea: the 
protection of environment and the future of the Law of the Sea. (Marta Ribeiro, ed.) Faculty of Law, University of Porto, Coimbra Editora, 2014, pp. 383-418.

70. “Satya Nandan's Contribution to the Development of the Precautionary Approach in International Law" in Peaceful Order in the World's Ocean: Essays in Honor of Satya Nandan (Michael Lodge and Myron Nordquist, eds.) Martinus Nijhoff, 2014, pp. 308-324.

71. "Governing the Blue: Governance of Areas beyond National Jurisdiction in the Twenty-First Century" in The Limits of Maritime Jurisdiction: Proceedings of the 2011 Law of the Sea Institute Conference, Wollongong Australia, 2011. Martinus Nijhoff, 2014, pp. 729-751.

72. "Can the UN Climate Regime respond to the Challenges of Sea Level Rise?" in Report of the Symposium in Honor of Jon Van Dyke, (2013) 35(2) University of Hawai'i Law Review 671-685.

73. "The Final Frontier: The Law of the Sea Convention and Areas beyond National Jurisdiction" in Proceedings of the 2012 Law of the Sea Institute Conference on Securing the Ocean for the Next Generation. Volume 1, Law of the Sea Institute Conference Papers Series, Martinus Nijhoff, 2013, pp. 1-15.

74. "A Green Emerging Market: India's Experiments with Market Based Mechanisms for Climate Mitigation" (2013) 7 Carbon and Climate Law Review 314-325 (with Anjum Rosha).

75. "Options to Protect Coastlines and Secure Maritime Jurisdictional Claims in the Face of Global Sea Level Rise" in Threatened Island Nations (Michael Gerard and Greg Warnier, eds.) Cambridge University Press, 2013, pp. 141-165 (with Clive Schofield).

76. "Introduction: The 1982 Law of the Sea Convention at 30: Successes, Challenges and New Agendas" in The 1982 Law of the Sea Convention at 30: Successes, Challenges and New Agendas (David Freestone, ed.) Martinus Nijhoff, 2013, pp. $1-8$.

77. "The International Legal Framework for Adaptation" Chapter 17 in Law of Adaptation to Climate Change: US and International Aspects (Michael Gerard and Katrina F. Kuh, eds.) American Bar Association Press, 2012, pp. 6o1-619.

78. "The Sargasso Sea Alliance: Seeking to Protect the Sargasso Sea." (2012) 27 International Journal of Marine and Coastal Law 647-655 (with Kate Killerlain Morrison).

79. "International Governance, Responsibility and Management of Areas beyond National Jurisdiction." (2012) 27 International Journal of Marine and Coastal Law 191-204. 
8o. "Responsibilities and Obligations of States Sponsoring Persons and Entities with respect to Activities in the Area" Advisory Opinion of the Seabed Disputes Chamber of ItLos (2011) 105 American Journal of International Law 755-761.

81. "The International Legal Framework for Climate Law" (2011) Finnish Environmental Law Review 4-13.

82. "The Long Slow Birth of a US Emissions Trading Regime" in Issues in Environmental Law: 30 Years of the Brazilian National Environmental Policy Act (edited by Rômulo S. R. Sampaio, Guilherme J. S. Leal and Antonio Augusto Reis). Lumen Juris in association with the Getulio Vargas Foudation - FGV, Rio de Janeiro, Brazil, 2011. 10 pp. (with David John Frenkil).

83. "Problems of High Seas Governance" in TheWorldOceanin Globalisation:Challenges and Responses, (Davor Vidas and Peter Johan Schei, eds) Martinus Nijhoff, 2011, pp. 99-130.

84. "Advisory Opinion of the Seabed Disputes Chamber of ITLOS on 'Responsibilities and Obligations of States Sponsoring Persons and Entities With Respect To Activities in the Area' "American Society of International Law Insight March 2011.

85. "The Long Slow Birth of a US Emissions Trading Regime" (2010) Tijdschriftvoor Energierecht No. 3-4 November, 2010, pp. 158-166 (with David John Frenkil).

85. "From Copenhagen to Cancun: Train Wreck or Paradigm Shift?" (2010) 12 Environmental Law Review 87-93.

87. "Law of the Sea" in Encyclopedia of Sustainability. Volume 3: The Law and Politics of Sustainability (Bosselman et al, eds.) Berkshire Publishing, New York, 2010, pp. $71-374$.

88. "The Kyoto Protocol" in Encyclopedia of Sustainability. Volume 3: The Law and Politics of Sustainability (Bosselman et al, eds.) Berkshire Publishing, New York, 2010, 3 pp. 57-36o.

89. "International Fisheries Commissions and Organizations" in Max Planck Encyclopedia of Public International Law (Rüdiger Wolfrum, ed.) Oxford University Press, 2010, 10pp.

9o. "The World Bank and Sustainable Development", in Research Handbook on International Environmental Law (Malgosia Fitzmaurice, David Ong and Panos Merkouris, eds.) Edward Elgar Publishing, London, 2010, pp. 138-16o.

91. "The Marine Environment" in The Reality of Precaution: Comparing Risk Regulation in the US and Europe (J.B. Wiener, M.D. Rogers, J.K. Hammitt \& P.H. Sand, eds,) RFF Press Washington DC and Earthscan, 2010, 177-200.

92. "Emissions Trading in the US: A New Regime Approaching?" Chapter IV in European Energy Law Report VII, (Groningen, 2010) pp. 75-94 (with David Frenkil).

93. "Climate Change and the Oceans" (2009) 3 Carbon and Climate Law Review 383-7. 
94. "The International Climate Change Legal and Institutional Framework: An Overview" in Legal Aspects of Carbon Trading: Kyoto, Copenhagen and Beyond (ed., with Charlotte Streck) Oxford University Press, 20o9, pp. 3-32.

95. "Summary and Outlook" in Legal Aspects of Carbon Trading: Kyoto, Copenhagen and Beyond (ed., with Charlotte Streck) Oxford University Press, 20o9, pp. 625-633.

96. "Modern Principles of High Seas Governance: The Legal Underpinnings" (2009) 39(1) Environmental Policy and Law 44-49.

97. "High Seas Fisheries" in Max Planck Encyclopedia of Public International Law (Rüdiger Wolfrum, ed.) Oxford University Press, 2009, 1opp.

98. "Editorial: Professor Gerard J. Mangone at 9o" (2008) 23 International Journal of Marine and Coastal Law 599-6oo (with Biliana Cicin-Sain).

99. "Editorial: Principles Applicable to Modern Oceans Governance" (2008) 23 International Journal of Marine and Coastal Law 385-391.

10o. "Ocean Iron Fertilization and International Law" Theme Section on: "Implications of large scale iron fertilization of the oceans" (2008) 364 Marine Ecology Progress Series 227-233 (with Rosemary Rayfuse).

101. "Meeting the Challenge of Climate Change: Legal Strategies for Reducing Greenhouse Gas Emissions" in Direito Ambiental Comparado (Arlindo Daibert, ed.) Editora Forum, Rio de Janeiro, Brazil, 2008, 207-226. (with Charlotte Streck).

102. "Foreword" to Climate Change and Forests: Emerging Policy and Market Opportunities (Charlotte Streck, Robert O'Sullivan, Toby Jason Smith and Richard Tarasofsky, eds) Brookings Institution, Washington DC, 2008, pp. i-v.

103. "A Decade of the Law of the Sea Convention: Is it a Success?" (2007) 39 George Washington University International Law Review 101-143, (Issue 3: Special Issue on the Symposium in Remembrance of Professor Louis Sohn).

104. "Environmental Challenges" in Panel: "Collapse: Can International Law protect the Earth's Natural Resources." American Society of International Law $107^{\text {st }}$ Annual Conference Proceedings, 2007, pp. 172-175.

105. "The Establishment, Role and Evolution of the Global Environment Facility: Operationalising Common but Differentiated Responsibility?" in Liber Amicorum for Thomas A. Mensah: Law of the Sea, Protection of the Marine Environment and Settlement of Disputes (Ndlaye and Wolfrum, eds.) Martinus Nijhoff, 2007, pp. 1077-1107.

106. "Editorial: Twenty-Five Years of the Law of the Sea Convention, 1982-2007." (2007) 22 International Journal of Marine and Coastal Law 1-4.

107. "Introduction: The Challenges of Implementing the Kyoto Mechanisms" in The Kyoto Protocol: Recent Developments in Carbon Finance, Special Issue of Environmental Liability, July 2007, pp. 1-9 (with Charlotte Streck). 
108. "Capacity Building and the Law of the Sea Convention: A View from the World Bank" in Law, Science and Ocean Management: Proceedings of the $30^{\text {th }}$ Virginia Law of the Sea Conference. (Nordquist, Norton Moore, et al., eds.) Martinus Nijhoff, The Hague, 2007, pp. 313-344.

109. "Ocean and Freshwater Resources." Chapter 15 in Oxford Handbook of International Environmental Law (Daniel Bodansky, Jutta Brunee and Ellen Hey, eds.) Oxford University Press, January 2007, pp. 337-361 (with Salman M.A. Salman).

110. "Protecting Our Oceans: New Challenges, New Solutions." Overview of Ocean and Fisheries Law Special Issue, Sustainable Development Law and Policy, American University Washington College of Law, Vol. VII Issue 1 (Fall 2006) 2-4.

111. "Guest Editorial: Human Rights and Development" Development Outreach, World Bank Institute, Washington, D.C., October 2006, 3-4 (with Joseph K. Ingram)

112. "World Bank Assistance in the Rule of Law Field." Proceedings of the International Bar Association Annual Conference, Chicago, 2006, 24pp (with Klaus Decker).

113. "The Law of the Sea: Progress and Prospects" Editors' Introduction to The Law of the Sea: Progress and Prospects (David Freestone, Richard Barnes and David Ong, eds.), Oxford, 2006, pp. 1-27 (with Richard Barnes and David Ong).

114. "The Role of the World Bank and the Global Environment Facility in the Implementation of the Regime of the Law of the Sea Convention" in The Law of the Sea: Progress and Prospects (David Freestone, Richard Barnes and David Ong, eds.) Oxford, 2006, pp. 308-326.

115. "Flexibility and Innovation in the Law of the Sea: Will the Los Convention amendment procedures ever be used?" in Stability and Change in the Law of the Sea: The Role of the Los Convention (Alex G. Oude Elferink, Ed.) Martinus Nijhoff, 2005, pp. 163-216 (with Alex G. Oude Elferink).

116. "The EU and Climate Change" in Reflections on 30 Years of EU Environmental Law: A High Level of Protection? (Richard Macrory, Ed.) Europa Law Publishing, Groningen, November 2005, pp. 87-108 (with Charlotte Streck)

117. "Introduction: The UN Framework Convention on Climate Change, the Kyoto Protocol and the Kyoto Mechanisms" in Legal Aspects of Implementing the Kyoto Protocol Mechanisms: Making Kyoto work (David Freestone and Charlotte Streck, eds.) Oxford, 2005, pp. 3-24.

118. "Summary and Outlook" in Legal Aspects of Implementing the Kyoto Protocol Mechanisms: Making Kyoto work (David Freestone and Charlotte Streck, eds.) Oxford, 2005, pp. 529-536 (with Charlotte Streck).

119. "Unfinished Business: Deep-Sea Fisheries and the Conservation of Marine Biodiversity beyond National Jurisdiction" (2004) 19 International Journal of Marine and Coastal Law 209-223 (ed., with Kristina Gjerde). 
120. “The World Bank's Extractive Industry Review" Proceedings of the $50^{\text {th }}$ Rocky Mountain Mineral Law Foundation Annual Institute, Vail, Colorado, 22 July 2004, sections 4.1-4.22 (with Roberto Dañino).

121. "Implementando a Precauçãio Cautelosamente: A Abordagem Precautória no Acordo das Nações Unidas sobre a Conservação e Ordenamento de Populações de Peixes Transzonais e de Populações de Peixes Altamente Migratórios" translated and republished in Princípio da Precaução, (Marcelo Dias Varella and Ana Flávia Barros-Platiau, eds.) Rio di Janeiro, Brazil 2003, pp. 233-274.

122. "Implementando o Princípio da Pracaução: Desafios e Oportunidades" (with Ellen Hey) translated and republished in Princípio da Precaução (Marcelo Dias Varella and Ana Flávia Barros-Platiau, eds.), Rio di Janeiro, Brazil 2003, pp. $205^{-232}$

123. "Incorporating Sustainable Development Concerns into the Development and Investment Process: The World Bank Experience." In Exploitation and Management of Natural Resources in the $27^{\text {st }}$ Century: The Challenge of Sustainable Development, (Malgosia Fitzmaurice and Milena Szuniewicz, eds.) Kluwer Law International, The Hague, 2003, pp. 91-112.

124. "The Environmental and Social Safeguard Policies of the World Bank and the evolving Role of the Inspection Panel" in Economic Globalization and Compliance with International Environmental Agreements, (Kanami Ishibashi, Alexandre Kiss and Dinah Shelton, eds.) Kluwer Law International, The Hague, 2003, pp. 139-156.

125. "International Financial Institutions and the Marine Environment: A view from the World Bank" in The Stockholm Declaration and Law of Marine Environment: Report of a Joint Conference Sponsored by the Center for Oceans Law and Policy, University of Virginia School of Law and the Faculty of Law, Stockholm University, (Myron H. Norquist, John Norton Moore and Said Mahmoudi, eds.), Kluwer Law International, The Hague, 2003, pp. 119-134.

126. "Prólogo" to Derecho Internacional Ambiental (Pierre Foy, Germán Vera, Fabián Novak and Sandra Namihas) Pontificia Universidad Católica de Peru, Lima, 2003, pp. 19-25.

127. "Introductory Note to the Text of the Instrument Establishing the World Bank Prototype Carbon Fund (PCF) and the First PCF Emissions Reductions Purchase Agreement" in The World Bank Legal Review: Law and Justice for Development, World Bank/Kluwer Law International, Washington D.C./The Hague, vol. 1, 2003, pp. $433-524$.

128. "The Year in Review: The World Bank" in Yearbook of International Environmental Law 2001, Vol. 12, Oxford University Press, 2003, pp.763-778 (with Charles Di Leva, Charlotte Streck, Hanneke van Tilburg, Salman Salman, Mohammed Bekhechi).

129. "The World Bank" in Encyclopaedia of Global Change (Andrew Goudie, ed.) Oxford University Press, 2002, 539. 
130. "The United Nations" in Encyclopaedia of Global Change (Andrew Goudie, ed.) Oxford University Press, 2002, 473.

131. "Environmental Law" in Encyclopaedia of Global Change (Andrew Goudie, ed.) Oxford University Press, 2002, pp.378-386 (with Laurence Boisson de Chazournes).

132. "The Year in Review: The World Bank" in Yearbook of International Environmental Law 200o, Vol. 11, Oxford University Press, 2001, pp. 755-765. (with Nightingale Rukuba-Ngaiza, Hanneke van Tilburg, Salman Salman, Mohammed Bekhechi).

133. "The World Bank's Prototype Carbon Fund: Mobilising new Resources for Sustainable Development" in (Sabine Schemmer-Schulte and Ko-Yung Tung, eds.) Liber Amicorum for Ibrahim S.I. Shihata, Kluwer Law International, The Hague, 2001, pp. 265-341.

134. "Implementing the Law of the Sea Convention, the FAo Compliance Agreement and the UN Fish Stocks Agreement: A view from the World Bank" in The FAO and the Law of the Sea (Myron Nordquist, ed.) Kluwer Law International, The Hague, 200o, pp. 167-181.

135. “Caution or Precaution: 'A rose by any other name ...?' " in "Symposium on the Southern Bluefin Tuna cases" in Yearbook of International Environmental Law 1999, Vol. 12, Oxford University Press, 200o, pp. 25-32.

136. "The Year in Review: The World Bank" in Yearbook of International Environmental Law 1999, Vol. 10, Oxford University Press, 200o, pp. 790-796. (with Jean Philippe Brisson, Nightingale Rukuba-Ngaiza, Hanneke van Tilburg, Alberto Ninio, Elly Gudmundsdottir, Mohammed Bekhechi).

137. "Implementing Precaution Cautiously: The Precautionary Approach in the 1995 Straddling Stocks Agreement" in Developments in International Fisheries Law (Ellen Hey, ed.), Kluwer Law International, 1999, pp. 287-325.

138. "International Environmental Law: Principles relevant to Transboundary Groundwater" in Groundwater: Legal and Policy Perspectives. Proceedings of World Bank Seminar (Salman M.A. Salman, ed.), World Bank Technical Paper No. 456, Washington D.C., 1999, pp. 191-204. (Arabic edition, 2003).

139. "The Year in Review: The World Bank" in Yearbook of International Environmental Law 1998, Vol. 9, Oxford University Press, 1999, pp.669-676. (with Charles Di Leva, Laurence Boisson de Chazournes, Mohammed Bekhechi and Junko Funahashi).

140. "Introduction" in International Law and Sustainable Development (Alan Boyle and David Freestone, eds.) 1999, Oxford University Press, pp. 1-21 (with Alan Boyle).

141. "International Fisheries Law since Rio - the continued rise of the Precautionary Principle" in International Law and Sustainable Development. (Alan Boyle and David Freestone, eds.) 1999, Oxford University Press, pp. 135-164. 
142. "The Challenge of Implementation: Some Concluding Notes" in International Law and Sustainable Development. (Alan Boyle and David Freestone, eds.) 1999, Oxford, pp. 359-564.

143. "Environmental Law: Concepts and Issues" in Partnerships for Global Ecosystems Management: Science Economics and Law: Proceedings and Reference Readings from the Fifth Annual World Bank Conference on Environmentally and Socially Sustainable Development. Ismail Serageldin and Joan Martin Brown (eds.), The World Bank, Washington DC, 1999, 182-191 (with Laurence Boisson de Chazournes).

144. "The 1995 Straddling Stocks Agreement in Context" in Sustainable Fisheries for the 21st Century, (J. Speir, ed.), Tulane Institute for Environmental Law and Policy, New Orleans, 1998, pp. 107-123.

145. "Towards an international environmental law of fisheries in the Year of the Oceans: oxymoron or paradigm shift?" IUCN/World Conservation Union, Environmental Law Programme Newsletter, May-September 1998, pp. 1-4.

146. "EC Action and Initiatives in Environmental Protection" in Beyond the Market: the EU and National Social Policy (David Hine and Hussein Kassim, eds.) The State and the European Union series, Routledge, 1998, pp. 178-211 (with Aaron McLoughlin).

147. "International Environmental Conventions" in Environmental Policy Section (Larry Kohler, ed.) of ILO Encyclopaedia of Occupational Health and Safety, International Labour Organisation, Geneva, 1998, Chapter 54, pp. 9-13.

148. "Towards Sustainable Tourism in the Wider Caribbean Region: Beyond Command and Control" in F. Weiss et al., Towards International Economic Law with a Human Face, Kluwer Law International, 1998, pp. 357-386 (with Neil Gunningham).

149. "The Year in Review: The World Bank" in Yearbook of International Environmental Law 1997, Vol. 8, Oxford University Press, 1998, 570-576. (with Charles Di Leva, Laurence Boisson de Chazournes, Mohammed Bekhechi and Junko Funahashi).

150. "The Impact of Subsidiarity" in Jane Holder (ed.) The Impact of Community Environmental Law in the United Kingdom, Wiley, 1997, pp. 87-100 (with Han Somsen).

151. "The Enforcement of the Wild Birds Directive: a case study" in Han Somsen (ed.), Protecting the European Environment: Enforcing Ec Environment Law, Blackstone Press, London, 1997, pp. 229-250.

152. "International Co-operation against Terrorism and the Development of International Law Principles of Jurisdiction" in Rosalyn Higgins and M. Flory (eds.), Terrorism and International Law: Anglo-French Perspectives, Sweet and Maxwell/Routledge, 1997, pp. 43-67. 
153. "The Year in Review: The World Bank" in Yearbook of International Environmental Law 1996, Vol. 7, Oxford University Press, 1997, pp. 477-48o (with Charles Di Leva, Laurence Boisson de Chazournes, Mohammed Bekhechi and Junko Funahashi).

154. "The New International Environmental Law of Fisheries: The 1995 Straddling Stocks Agreement” (1996) 7 Yearbook of International Environmental Law 3-49 (with Zen Makuch).

155. "A Comment", in Proceedings of the 28th Annual Conference of the Law of the Sea Institute, 11-15July 1994, Honolulu, Hawaii. The Law of the Sea Institute, Honolulu, 1996, pp. $5^{-6 .}$

156. "New Directions in European Environmental Law" in B. Boer, R. Fowler and N. Gunningham (eds.), Environmental Outlook 1995: Law and Policy, The Federation Press, Sydney, Australia, 1996, pp. 29-52.

157. "Legal Implications of Global Climate Change for Bangladesh" in R.A. Warrick and Q.K. Ahmad (eds), The Implications of Climate and Sea-Level Change for Bangladesh, Kluwer Academic Publishers, Dordrecht, 1996, pp. 289-334 (with M. Farooque and S. R. Jahan).

158. "The Conservation of Marine Ecosystems under International Law" in M. Bowman and C. Redgwell (eds.), International Law and the Conservation of Marine Biodiversity, Kluwer Law International, 1996, pp. 91-107.

159. "Contributions of Ocean Resources to the East Asian Economy. A Commentary", in Seoung-Yong Hong; Edward L. Miles and Choon-ho Park (eds), The Role of the Oceans in the 21st Century, Proceedings of the 27th Annual Conference of the Law of the Sea Institute, 13-16th July 1993, Seoul, Republic of Korea. The Law of the Sea Institute, Honolulu, 1995, pp. 554-559.

16o. "Canada and EU reach Agreement to settle the Estai Dispute" (1995) 10 International Journal of Marine and Coastal Law 397-411; abridged version also published in (1995) 4 European Environmental Law Review 270-272.

161. "International Legal Issues" in Fisheries in The Future: Sustainability or Extinction? Proceedings of Greenwich Forum Conference, 24 April 1995, 1opp.

162. "The Effective Conservation and Management of High Seas Living Resources: Towards a new Regime?" (1995) 5 Canterbury Law Review 341-362.

163. "Fisheries Issues" in Proceedings of Greenwich Forum Conference to Mark the Entry into Force of the Law of the Sea Convention, 28 November 1994, pp. 15-27.

164. "The Road From Rio: International Environmental Law after the Earth Summit" (1994) 6 Journal of Environmental Law 193-218.

165. "EC Environmental Law after Maastricht" (1994) 45 Northern Ireland Legal Quarterly 152-176 (with D. Ryland).

166. "The Principle of Co-operation: Terrorism" in A.V. Lowe and C. Warbrick (eds.), The United Nations and the Principles of International Law: Essays in Memory of Professor Michael Akehurst, Routledge, 1994, pp. 137-159. 
167. "Sea Level Rise and Maritime Boundaries: international implications of impacts and responses" in Gerald Blake (ed.) International Boundaries; Fresh Perspectives, Volume 5, Routledge, 1994, pp. 73-9o (with J.S. Pethick).

168. "The Implementation of the 1990 Kingston Protocol to the Cartagena Convention" Coastal Zone '93, Proceedings of the 1993 Conference on Coastal and Ocean Management, New Orleans, July 1993, Volume 3, pp. 2254-63.

169. "UNCED and the Marine Environment: A comment" in The Law of the Sea: New Worlds, New Discoveries; Proceedings of the 26th Law of the Sea Institute Annual Conference, Genoa, June 1992. The Law of the Sea Institute, Honolulu, 1994, pp. $172-175$.

170. "Exclusive Economic Zones in the North Sea" (1993) 26 Marine Pollution Bulletin 176-178.

171. "The North Sea Declaration on the Co-ordinated Extension of Jurisdiction" (1993) 8 International Journal of Marine and Coastal Law 172-175.

172. "International Marine Environmental Treaties" in (P. Sand, Ed), The Effectiveness of International Environmental Treaties, Cambridge: Grotius Press, 1992, pp. 149254 (with Alan Boyle, K. Kummer and D. Ong).

173. "The Maastricht Treaty and the Environment" (1992) 1 European Environmental Law Review 20-22.

174. "Some Institutional Implications of the Establishment of Exclusive Economic Zones by the Member States of the European Community" (1992) 22 Ocean Development and International Law 97-117. (Special issue on "Europe's Offshore Waters " edited by Professor Barbara Kwiatkowska).

175. "Interesting Times ahead on the Ec Agenda" (1992) 3 Water Law 158.

176. The Precautionary Principle" Chapter 3 , in (Robin Churchill and David Freestone, eds) International Law and Global Climate Change, 1991, pp. 21-40.

177. "International Law and Sea Level Rise" Chapter 8, in (Robin Churchill and David Freestone, eds) International Law and Global Climate Change, 1991, pp. 109-125.

178. "Conclusions" in (Robin Churchill and David Freestone, eds) International Law and Global Climate Change, 1991, pp. 201-208 (with Robin Churchill).

179. "European Environmental Law and Policy" (1991) 18 Journal of Law and Society 135- 154. (Environmental Law Special Issue, edited by R.R. Churchill, J. Gibson and L. Warren). Also published contemporaneously as Law, Policy and the Environment, Oxford, Basil Blackwell, April 1991.

180. "Problems of Coastal Zone Management in Antigua and Barbuda" in (G. Cambers, ed.) Coastlines of the World: The Caribbean, published by the Coastal Zone '91 Symposium, Long Beach, California, July 1991, 61-69.

181. "The International North Sea Conferences: A new force in regional environmental co-operation" for Coastal Zone '91, Long Beach, California, July 1991, pp. 149-159. 
182. "Maritime Boundaries and Sea level Rise" CoastalZone '91, Long Beach California, July 1991. (abstract only, with J.S. Pethick).

183. "UK/Argentina Co-operation on Fisheries Conservation" (1991) 6 International Journal of Estuarine and Coastal Law 145-150.

184. "The Leybucht Dikes Case: Some wider implications." (1991) 2 Water Law 152-156.

185. "Integrated Coastal Zone Management: The Problem of Boundaries" in (J. Clark, ed.) The Status of Integrated Coastal Zone Management: A Global Assessment CAM PNET (Coastal Area Management and Planning Network, Rosenstiel School of Marine and Atmospheric Science, University of Miami, 1991, pp. 75-77.

186. "Problems of Coastal Zone Management in Antigua and Barbuda" in (J. Clark, ed.) The Status of Integrated Coastal Zone Management: A Global Assessment CAM PNET (Coastal Area Management and Planning Network, Rosenstiel School of Marine and Atmospheric Science, University of Miami, 1991, pp. 86-91.

187. "Protection of Wildlife and Ecosystems in the Wider Caribbean - the new Protocol on Protected Areas and Wildlife" (1991) 22 Marine Pollution Bulletin $578-581$.

188. "International Protection of the Earth's Atmosphere (Conclusions of the Bievres Round-table)" (1991) 21 International Environmental Policy and Law 61-63 (with P.-M. Dupuy).

189. "Introduction" to The North Sea: Perspectives on Regional Environmental Co-operation, (David Freestone and Ton IJlstra, eds.) Graham and Trotman/Martinus Nijhoff, London/Dordrecht, 199o, pp. 1-4 (with Ton IJlstra).

19o. "Conclusions" to The North Sea: Perspectives on Regional Environmental Co-operation, (David Freestone and Ton IJlstra, eds.) Graham and Trotman/Martinus Nijhoff, London/Dordrecht, 199o, pp. 304-310. (with Ton IJlstra).

191. "Specially Protected Areas and Wildlife in the Caribbean: the 1990 Kingston Protocol to the Cartagena Convention" (1990) 5 International Journal of Estuarine and Coastal Law 396-416.

192. "The United Nations Convention on the Rights of the Child" in Children and the Law: Essays in Honour of Professor H.K. Bevan (David Freestone, ed.) University of Hull Press, 1990, pp. 288-320.

193. "Maritime Boundary Delimitation in the Eastern Caribbean" in International Boundaries and Boundary Conflict Resolution (C. Grundy-Warr, ed.) Proceedings of the 1989 Conference, International Boundaries Research Unit, Durham University, 199o, pp. 195-210.

194. "The Third International Conference for the Protection of the North Sea, The Hague, March 1990" (1990) 1 Water Law 17-20.

195. "Preparing for the Rising Tides" (1990) 14 Marine Policy 456-7. 
196. "International Legal Implications of Coastal Adjustments under Sea Level Rise: Active or Passive Response?" in Changing Climate and the Coast. Vol. 1: Adaptive Responses and their Economic, Environmental, and Institutional Implications. Report to Intergovernmental Panel on Climate Change (IPCC) from the Miami Conference on Adaptive Options to Sea Level Rise and Climate Change (James G. Titus ed.), UnEP/WMO/NOAA/EPA, 199o, pp. 237-256 (with J.S. Pethick).

197. "Legal and Institutional Implications (of sea-level rise)" (with Committee: G. Cano (Argentina), D. Ponce-Nava (Mexico), R. Fischman (USA) and Js Pethick (UK)) in Changing Climate and the Coast (above) 28-29.

198. "Fisheries Management in the Eastern Caribbean", Proceedings of the Coastal Zone '89 Symposium, Charleston, South Carolina, 1989, Vol. 3, pp. 2315-2319.

199. "Maritime Boundaries in the Eastern Caribbean", Proceedings of the Coastal Zone '89 Symposium, Charleston, South Carolina, 1989, Vol. 4, pp. 3494-35o1.

20o. "Coastal Zone Management in Antigua and Barbuda", Proceedings of the Coastal Zone '89 Symposium, Charleston, South Carolina, 1989, Vol. 2, pp. 1446.

201. "The Maritime Boundary in the Area between Greenland and Jan Mayen (Denmark/Norway)", International Journal of Estuarine and Coastal Law, Graham and Trotman Ltd, vol. 4, 1989, 67-70.

202. "The Land Island and Maritime Frontier Case (El Salvador/Honduras)", International Journal of Estuarine and Coastal Law, Graham and Trotman Ltd, vol. $3,1988,342-344$.

203. "The 1988 International Convention for the Suppression of Unlawful Acts against the Safety of Maritime Navigation" (1988) 3 International Journal of Estuarine and Coastal Law 305-327.

204. "The Legal Regulation of the Humber" (with T. Burton) in The Humber Estuary, above, 49-104. [Report of a commissioned study undertaken for Shell Expro Ltd by the Institute of Estuarine and Coastal Studies.]

205. "Nuclear Weapon Free Zones", in Nuclear Weapons and International Law, (Istvan Pogany, ed.) Avebury/Gower Press, 1987, pp. 176-216. (with J. Scott Davidson).

206. "Treaties, Extradition and Diplomatic Immunity: Some Recent Developments" (1986) 35 International and Comparative Law Quarterly 425-436(with J.S. Davidson, A.V. Lowe and C. Warbrick).

207. "Community Competence and Part III of the Single European Act" (1986) 23 Common Market Law Review 793-801 (with J. Scott Davidson).

208. "The Control of Pollution Act, 1974, and Tidal Waters: Problems of the Implementation of Part II" (1986) 1 International Journal of Estuarine and Coastal Law 241- 268 (with Tim Burton). 
209. “The European Union Treaty: Legal Problems" in European Union: the European Community in Search of a Future, (Juliet Lodge, ed.)) Macmillan, London, 1986, pp. 125-15o. (with J. Scott Davidson).

210. "The EEC Treaty and Common Action on Terrorism" (1985) 4 Yearbook of European Law 207-230.

211. "Some Problems of the Draft Treaty on European Union" (1984) 9 European Law Review 387-400 (with Juliet Lodge and J. Scott Davidson).

212. "The Common Fisheries Policy" in Institutions and Policies of the European Communities (Juliet Lodge, ed.), Francis Pinter, London, 1983, pp. 77-84. (with A. Fleisch).

213. "The Common Fisheries Policy" in The European Community: Bibliographical Excursions (Juliet Lodge, ed.), Francis Pinter, London, 1983, pp. 107-116.

214. "The European Court of Justice" in Institutions and Policies of the European Communities, (Juliet Lodge, ed.) Francis Pinter, London, 1983, pp. 43-53.

215. "The European Court of Justice" in The European Community: Bibliographical Excursions, (Juliet Lodge, ed.) Francis Pinter, London, 1983, pp. 77-87.

216. "The European Community and Terrorism: Political and Legal Aspects", in Terrorism in Europe, (Yonah Alexander and Kenneth A. Myers, eds.) London, Croom Helm, 1982, pp. 79-101. (with J. Lodge).

217. "Sex Discrimination: How far can European Community Law be used in Industrial Tribunals?" Legal Action Group Bulletin, 1982, pp. 5-7.

218. "Equal pay in the European Court" (1982) 45 Modern Law Review 81-87.

219. "Legal Responses to Terrorism: Towards European Co-operation?" in, Terrorism: A Challenge to the State, (Juliet Lodge, ed.) Martin Robertson, Oxford, and St Martin's Press, 1981, pp. 195-224.

220. "The Making of the English Criminal Law: Sir John Jervis and His Acts" Criminal Law Review, 1980, pp. 5-16. (with J.C. Richardson).

221. "The Supremacy of Community Law in National Courts." (1979) 42 Modern Law Review 220-223.

222. “Unenforceable Community Rights?" (1978) 41 The Modern Law Review 346-352.

\section{Official Reports, etc.}

223. Co-Chairs' Report, Workshop on Governance of Marine Areas beyond National Jurisdiction: Management Issues and Policy Options November 3-5, 2008, Singapore (ed., with Professor Biliana Cicin-Sain and others).

224. Co-Chairs' Report, Strategic Planning Workshop on Global Ocean Issues in Marine Areas Beyond National Jurisdiction in the Context of Climate Change, Nice, France, January 23-25, 2008. (ed., with Biliana Cicin-Sain). 
225. Co-Chairs' Report Workshop on High Seas Governance for the $21^{\text {st }}$ Century New York City, 17-19 October 2007 (ed., with Rosemary Rayfuse, Kristina Gjerde and Professor David Vanderzwaag).

226. Making Sustainable Commitments: An Environment Strategy for the World Bank, The World Bank, Wahsington DC, 2001 (with many others).

227. Institutional Arrangements for Coastal Zone Management in Belize, Phase One Draft Report for Global Environment Facility Project BZE/92/G31 on Sustainable Development and Management of Biologically Diverse Coastal Resources in Belize, November 1995, 19pp.

228. Invited Evidence to House of Lords Select Committee on Science and Technology, Committee IV on Fish Stock Conservation and Management, House of Lords (1995-96) 2nd. Rep. HL Paper 25, pp.12off.

229. Draft Convention for Fisheries and Conservation of Living Resources of the Black Sea (CFCLRBS), (with Professor P.W. Birnie), Working Document for Experts Meeting, Istanbul, 13-15 December 1995, 2opp.

230. Report on the Role of Regional and Intergovernmental Organisations in Marine Fisheries Management. Prepared for the Fisheries Secretary, Ministry of Agriculture, Fisheries and Food, London, as a background paper for the London Oceans Workshop on "Environmental Science, Comprehensiveness and Consistency In Global Decision Making On The Oceans" 30 Nov. -2 Dec. 1995, 12opp.

231. Priorities for Action on Land Based Sources of Marine Pollution, (with Professor P.W. Birnie for ACOPS Legal Committee), Background paper prepared by the Advisory Committee for Protection of the Sea (Acops) for the Montreal Meeting of Experts on Control of Marine Pollution from Land Based Sources, 6-10 June 1994, May 1994, 1opp.

232. Mexico City Recommendations on Sustainable Development of Tourism in the Wider Caribbean (Joint Rapporteur with Paola Caballeros, Colombia) UNEP/ AC OPs Seminar on Sustainable Development of Tourism in the Wider Caribbean, Mexico City 18-2o April 1995. 1opp.

233. The Burden of Proof in Natural Resources Legislation, Paper for Legal Office, Food and Agriculture Organisation of UN, Rome, 1994, 25pp.

234. Issues To Be Addressed In The Convention For Fisheries And Conservation Of Living Resources Of The Black Sea (CFCLRBS), (with Professor P.W. Birnie), Working Document For Experts Meeting, Istanbul, October 1994, 28pp.

235. Impacts of Climate Change on Bangladesh: National and International Legal Aspects (with M Farooque and S. Jahan), Briefing Document 5, CEARS and Bangladesh Unnayan Parishad, 1993, 24pp. 
236. Relevance and Application of the Principle of Precautionary Action to the Caribbean Environment Programme. Secretariat Paper prepared as consultant for the CEP Meeting of Experts and the Third Meeting of the Parties to the Cartagena Convention, 20 pp.+ 5pp. UN OCA/CAR WG.10/INF.4, November 1992.

237. Requirements of Proof for Conservation in High Seas Fisheries. Paper for Food and Agricultural Organisation of the United Nations, 1992, 27pp.

238. Particularly Sensitive Sea Areas: Report of Third International Meeting of Legal Experts (with Ellen Hey, D. Ong and others), held at Texel. The Netherlands, 14 June 1994. Report submitted as Information Paper to International Maritime Organisation, Navigational Subcommittee, September 1994 and Marine Environment Protection Committee, October 1994, (MEPC 37/INF.oo).

239. Particularly Sensitive Sea Areas: Report of Second International Meeting of Legal Experts (with D. Ong, K Gjerde and others), held at Nyköping, Sweden, 2-4 June 1993. Report submitted as Information Paper to International Maritime Organisation, Marine Environment Protection Committee, October 1993 (MEPC 35/INF.17).

240. Particularly Sensitive Sea Areas: Report of International Meeting of Legal Experts, held at University of Hull Law School, 20-21 July 1992. Report submitted as Information Paper to International Maritime Organisation, Marine Environment Protection Committee, October 1992 (MEPC 33/INF.27).

241. Marine Environmental Treaties (with D. Ong, A.E. Boyle and K. Kummer) United Nations Conference on Environment and Development, Research Paper No. 27, 1992, 13opp. 